\title{
Development of an Automated and Dedicated Measuring System of Tube Dimensions Using 1d and 2d Laser Displacement Sensors
}

Department of Mechanical Engineering B S Abdur Rahman Crescent Institute of Science and Technology, Chenna

Sathickbasha K

Department of Mechanical Engineering B S Abdur Rahman Crescent Institute of Science and Technology, Chennai India

Sai Balaji M A

Department of Mechanical Engineering B S Abdur Rahman Crescent Institute of Science and Technology, Chennai India

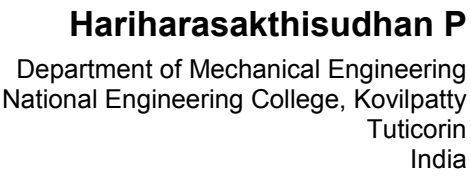

\section{INTRODUCTION}

Tubes are the main parts in creating value-added products such as automobile front fork suspensions and camshafts. In the mass production of tubes the ID, OD, length, run-out and chamfer angle are the significant parameters to be inspected and it should be within the tolerance limit given by the customer. The dimension tolerances of these components are in microns $(20-100 \mu \mathrm{m})$. The machining error above the (more than $100 \mu \mathrm{m}$ ) tolerances of these automobile components leads to create many problems like oil leakages in hydraulic suspension systems, reduced engine perfor-mance due to cam runout and creates safety issues. Generally, In the tube product industries, the quality inspection of the manufactured tubes is performed by manual inspection methods using statistical sampling procedures. But for automobile components like suspension tubes and camshafts most of the industries are inspecting their finished product by Manual-intensive inspection methods for each and every piece before supplied to the customer. Due to unskilled labor and human fatigue there is the very high probability of imprecise inspection on the finished product [1]. Therefore the development of an automated system for inspection is necessary in order to avoid the imprecise inspection by manual methods [2]. There are many existing automatic systems of inspections are available such as the use of

Received: June 2018, Accepted: September 2018

Correspondence to: Mr. Surya Rajan B

B S Abdur Rahman Crescent Institute of Science and

Technology, Chennai, India.

E-mail: suryarajan.b@gmail.com

doi: $10.5937 /$ fmet1901122R

(C) Faculty of Mechanical Engineering, Belgrade. All rights reserved contact type of inspection instruments like linear variable differential transducers (LVDT) and machine vision systems, etc [3]. But the repeatability and work environment for these instruments are having limitations in the high noisy production shops. This paper focused on the development of a Special Purpose Machine (SPM) with the pneumatic automation system and one-dimensional as well as two-dimensional laser displacement sensors to measures or examines tubular pieces for its dimensions.

\section{EXPERIMENTAL SETUP}

\subsection{Design and development of SPM}

In this SPM, there are four main stations were placed in series, which are receiving Station, tube cleaning station, OD run-out as well as length inspection station and chamfer angle, OD and ID Inspection station for both LH side as well as RH side (Figure 1). All the Stations are mounted on the single base plate of $20 \mathrm{~mm}$ thick for the step by step inspection of all tube dimensional parameters. The flatness of the base plate is maintained less than 50 microns on each and every 2D surface to ensure the accurate results in measurement.

All the tubes are being loaded in the receiving station for inspection of the tube dimensional parameters. This station receives the tube on the two Vblock locators. The tube production system conveyor is coupled with this station for the continuous loading of the tubes. The second station is tube cleaning station, the high-pressure air is passed inside the tube for removing the machined particles inside the tubes which are generally affecting the laser measuring process. 


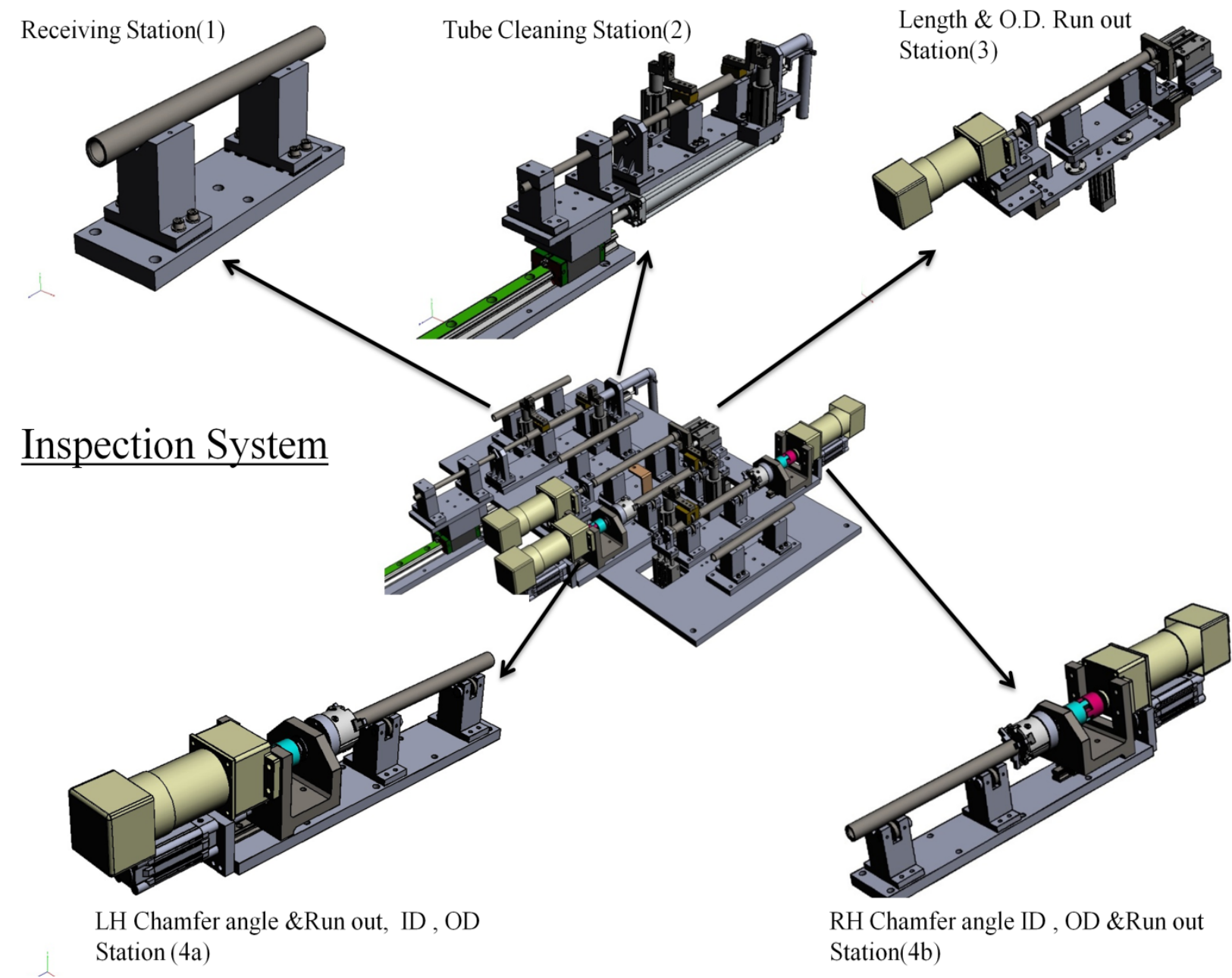

\section{Figure 1 Multi-station inspection system}

In the third station, the tube parameter such as length and OD run-out of the tubes are being inspected using a 1D laser displacement sensors (KEYENCE IL 300 for length measurement and IL 100 for OD run-out measurement). In station four, chamfer angle, OD, and ID, of the tube are being inspected using a 2D laser scanner (KEYENCE LJ-G080), which is mounted on the pneumatic guide cylinder rod end coupled with Linear Motion (LM) guide slider.

After the completion of all the measurements, the tube arrives at the last station for tube separation in the corresponding boxes for the error rework and packaging. This entire inspection-fixture is mounted on the frame which made up of square steel tubes of a cross section $3 \times 3$ inch and the thickness of the frame steel tube is $6 \mathrm{~mm}$ the square steel tubes are cut and welded together into a base frame.

\subsubsection{Tube Transfer System}

The tube transfer system is used to transfer the tubes from one station to another station automatically. Six pneumatic parallel gripper cylinders (Figure 2) are used in this system to grab the tubes present in the stations. Another two pneumatic linear cylinders are used for pick (vertical move) and place (Horizontal move) the tubes from one station to another. So this transfer system could give the planar motion with two degrees of freedom. All the six grippers are mounted on the single frame which slides vertically on the sliding rod of $30 \mathrm{~mm}$ dia. The linear bearings are used to obtain the linear motion of the gripper frame to the distance of $150 \mathrm{~mm}$ horizontally. The main parts of the tube transfer system are shown in Figure 2.

Since the laser scanners are very sensitive towards the external influences, transfer of vibration from the tube transfer system to inspection system has to be avoided. So, the tube transfer system is mounted on the separate frame that is the outer frame of the SPM as shown in Figure 3.

Figure 3 shows the inspection system combined with the tube transfer system where the inspection and tube transfer between various stations are automated by combining the inspection and transfer system. Next step in this automated process is to separate the tubes based on the dimensional error and rework if required on the tube.

\subsubsection{Tube Separation System}

This system picks the tube from the final station of the inspection system and drops the tubes in the corresponding boxes based on the rework required on the tube. If there is no rework required on the tube this separation unit shifts the tube to the packaging conveyor. 


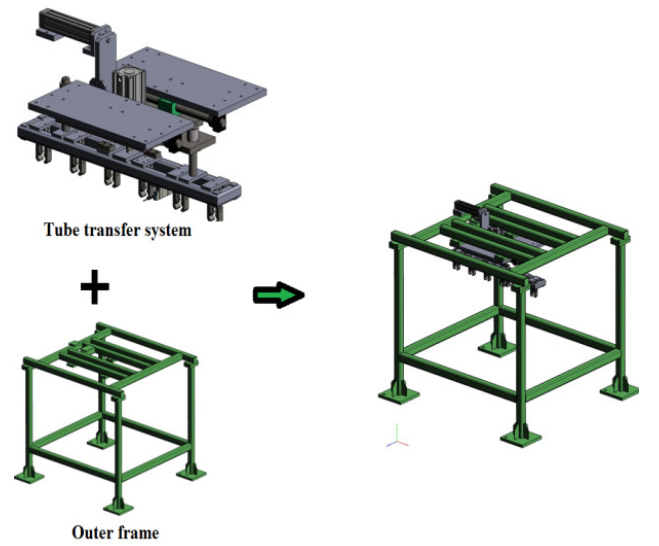

Figure 2 Tube transfer system
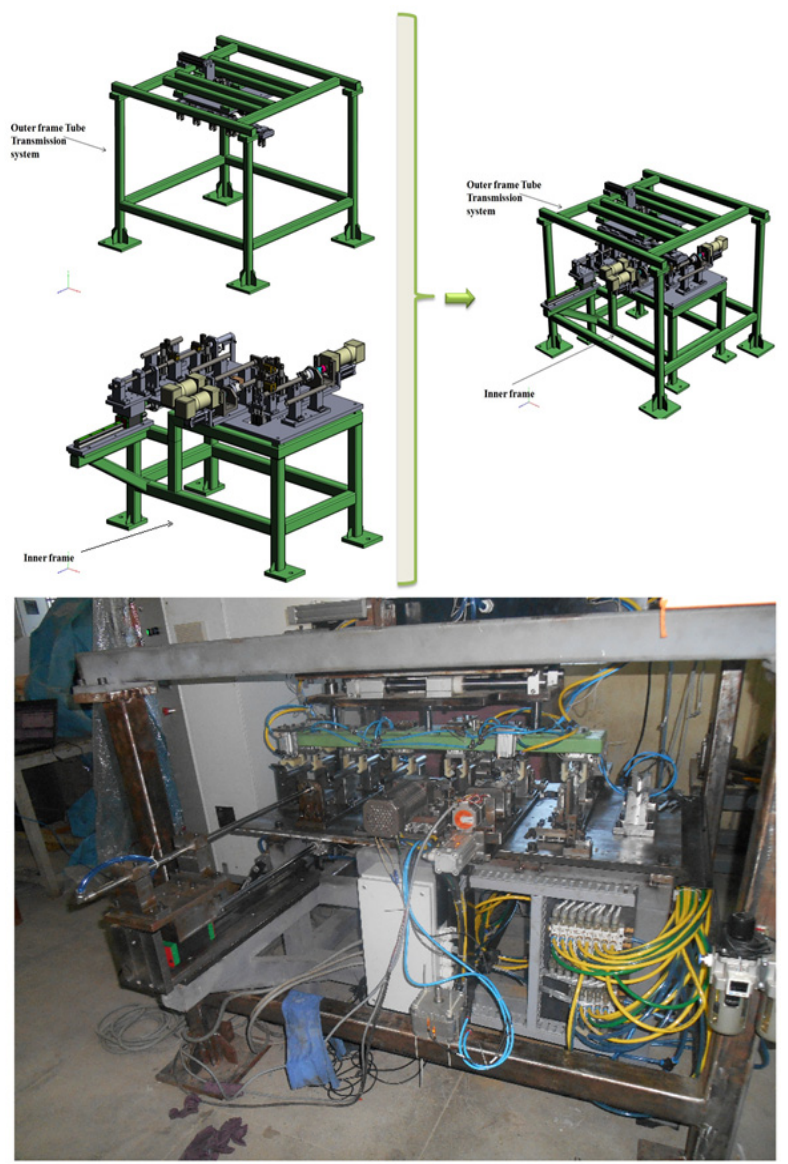

Figure 3 CAD model \& manufactured and assembled inspection system with tube transfer

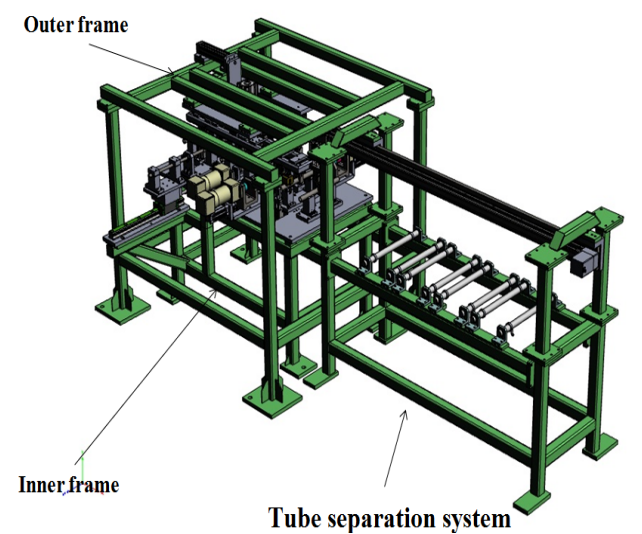

Figure 4 CAD model of tube inspection machine

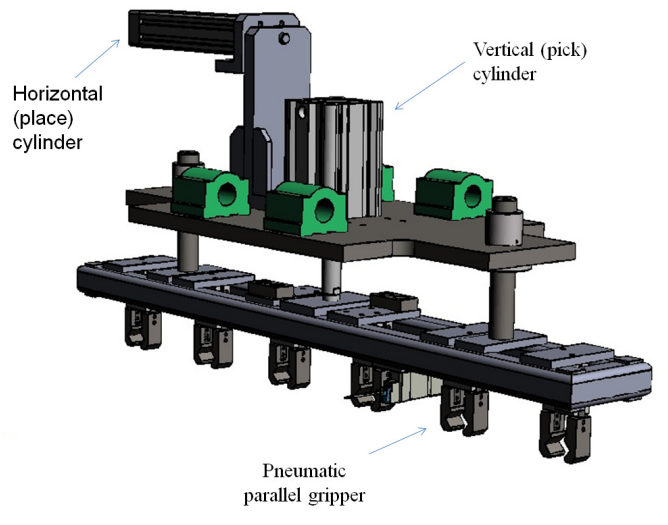

3. METHOD OF MEASUREMENT

Selection of measuring sensors is important in the case of the dimensional inspection system. In this work the noncontact laser displacement sensors work based on optical triangulation principle is used as a measuring unit $[4,5,6]$ for the industrial shop floor environment. 1D laser displacement sensor was used for measuring the OD run-out and Length. The model and specifications of the selected sensors were shown in Table 1.

\subsection{Length and OD-runout measurement}

The position of the 1D laser sensors are shown in Figure 5(a). The 1D laser displacement sensor with the measuring range of $160-450 \mathrm{~mm}$ is used to measure the length of the tube. The position sensor is installed to detect the presence of the tube in the measuring station. Once the position sensor detects the presence of the tube the measuring sequence starts. After ensuring the presence of the tube, it is auto-centered by the cone gripper as shown in the Figur 5 (a). The 1D laser sensor triggers the laser beam and hits the laser beam target on the longitudinally opposite side and measures the distance in terms of the length of the tube.

Table 1 Specifications of 1D laser sensor

\begin{tabular}{|c|c|c|}
\hline $\begin{array}{l}\text { Laser sensors/ } \\
\text { Specifications }\end{array}$ & IL 300 & IL 100 \\
\hline $\begin{array}{l}\text { Measuring } \\
\text { Range }\end{array}$ & $160-450 \mathrm{~mm}$ & $75-130 \mathrm{~mm}$ \\
\hline Repeatability & $4 \mu \mathrm{m}$ & $30 \mu \mathrm{m}$ \\
\hline Assured Life & 20 million cycles & 20 million cycles \\
\hline Linearity & $\begin{array}{l} \pm 0.25 \% \text { of F.S. } \\
(160 \text { to } 440 \mathrm{~mm} \\
6.30 " \text { to } 17.32 ")\end{array}$ & $\begin{array}{c} \pm 0.15 \% \text { of F.S. } \\
\text { (80-120 MM 3.15” } \\
\text { TO 4.72”) }\end{array}$ \\
\hline Type & \multicolumn{2}{|c|}{$\begin{array}{l}\text { IL Series CMOS Multi-function analog } \\
\text { laser sensor. }\end{array}$} \\
\hline Sampling rate & \multicolumn{2}{|c|}{$2 \mathrm{~ms}$} \\
\hline $\begin{array}{l}\text { Environmental } \\
\text { resistance }\end{array}$ & \multicolumn{2}{|c|}{$\begin{array}{l}\text { Works in the temperature range }-10 \text { to } \\
+50^{\circ} \mathrm{C} \text {, relative humidity } 35 \text { to } 80 \% \\
\mathrm{RH} \text {, vibration } 10-50 \mathrm{~Hz} \text { double } \\
\text { amplitude } 1.5 \mathrm{~mm} 0.06 \text { " in } \mathrm{XYZ} \text { axis: } \\
2 \mathrm{Hrs} \text {. }\end{array}$} \\
\hline $\begin{array}{c}\text { Analog Voltage } \\
\text { output }\end{array}$ & \multicolumn{2}{|c|}{$\begin{array}{l} \pm 5 \mathrm{~V}, 1 \text { to } 5 \mathrm{~V}, 0 \text { to } 5 \mathrm{~V} \text { Output } \\
\text { impedence } 100 \Omega\end{array}$} \\
\hline $\begin{array}{l}\text { Analog current } \\
\text { output }\end{array}$ & \multicolumn{2}{|c|}{$\begin{array}{l}4 \text { to } 20 \mathrm{~mA} \text { Maximum load resistance of } \\
350 \Omega\end{array}$} \\
\hline
\end{tabular}


(a)

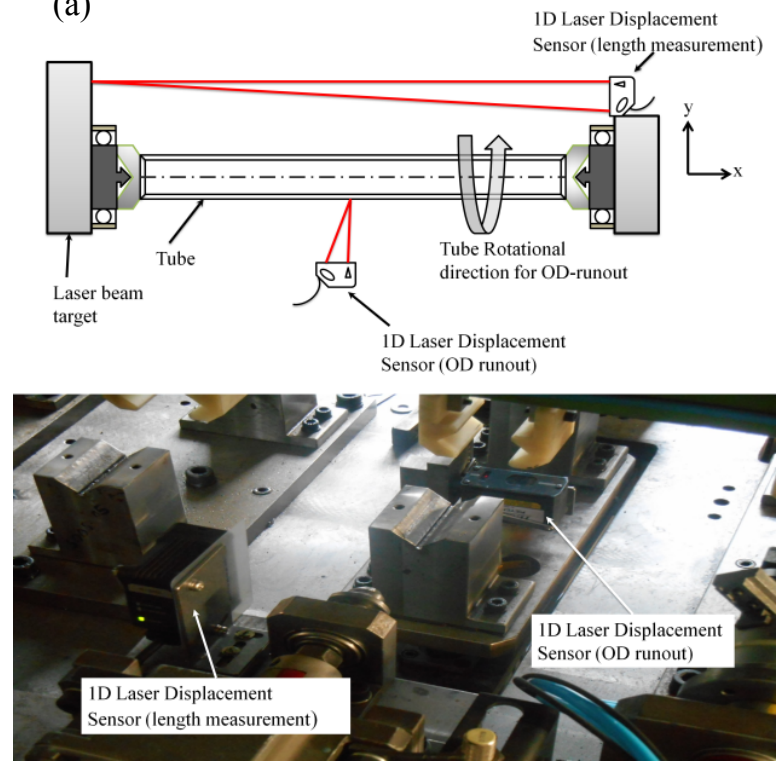

$\begin{array}{ll}\mathrm{y} & (\mathrm{b})\end{array}$
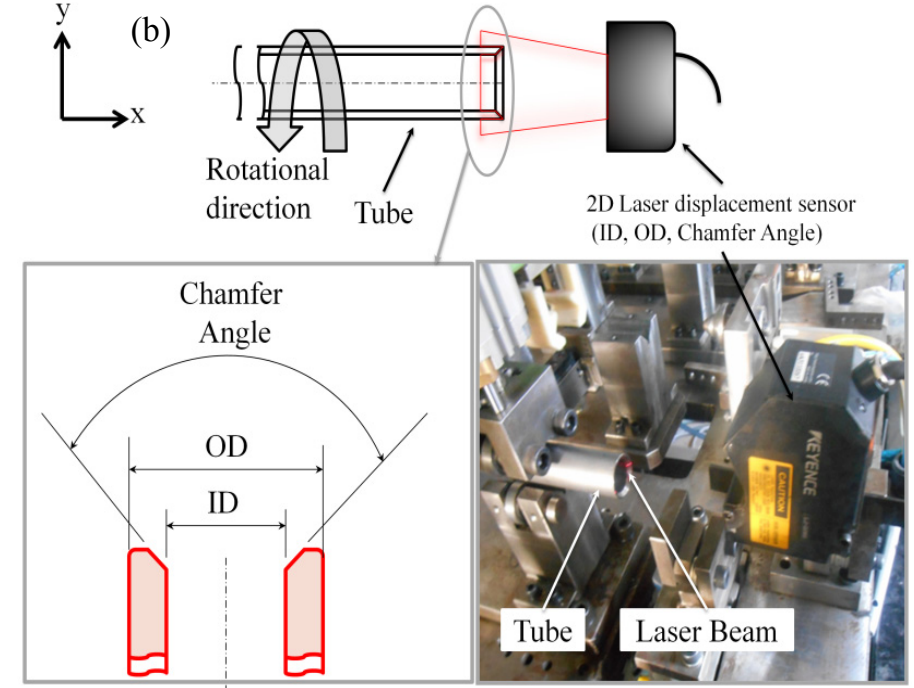

Figure 5 (a) \& (b) One and two dimensional laser sensors used for dimensional inspection

The one-dimensional laser sensor having the measuring range of $75-130 \mathrm{~mm}$ is used for the measurement of runout of the tube. The repeatability of the sensor is 4-30 $\mu \mathrm{m}$ and a resolution of $1 \mu \mathrm{m}[7,8]$. The step-down motor and rolling center is used to rotate the tube for the inspection of run-out. The tube rotated about its axis at the speed of 30 revolutions per minute. The laser sensor measures the displacements with the frequency of 30 $\mathrm{Hz}$. The difference between the maximum and the minimum displacement value is measured as the ODrunout.

\subsection{ID, OD and Chamfer Angle measurement}

The two-dimensional laser sensors works based on laser triangulation measurement principle is used to measure the OD, ID, chamfer angle [9] of the tube in both the LH side and RH side of the tube.

Table 2 Specifications of 2D Laser Scanner

\begin{tabular}{|c|c|}
\hline $\begin{array}{l}\text { Laser sensor/ } \\
\text { Specifications }\end{array}$ & Details \\
\hline Model & KEYENCE, LJ-G080 \\
\hline Reference distance & $30 \mathrm{~mm}$ \\
\hline $\begin{array}{l}\text { Measuring Range } \\
\text { (Z-axis) }\end{array}$ & $80 \pm 23 \mathrm{~mm}$. \\
\hline $\begin{array}{l}\text { Measuring Width } \\
\text { (X-axis) }\end{array}$ & $39 \mathrm{~mm} @$ measuring range $80 \mathrm{~mm}$. \\
\hline Light source & $\begin{array}{l}\text { A red semiconductor laser, wave } \\
\text { length } 650 \mathrm{~nm} \text { (visible light). }\end{array}$ \\
\hline Repeatability & $\begin{array}{c}1 \mu \mathrm{m} \text { in } \mathrm{Z} \text { axis and } 10 \mu \mathrm{m} \text { in } \mathrm{X}^{-} \\
\text {axis. }\end{array}$ \\
\hline Linearity (Z-axis) & $\pm 0.1 \%$ of F.S. \\
\hline $\begin{array}{l}\text { Environmental } \\
\text { resistance }\end{array}$ & $\begin{array}{l}\text { Enclosure Rating- IP67 (IES } \\
60529), \text { Works in the temperature } \\
\text { range } 0 \text { to }+50{ }^{\circ} \mathrm{C} \text {, relative } \\
\text { humidity } 35 \text { to } 85 \% \text { RH, vibration } \\
10-50 \mathrm{~Hz} \text { double amplitude } 1.5 \\
\text { mm } 0.06 " \text { in XYZ axis: } 2 \mathrm{Hrs} \text {. }\end{array}$ \\
\hline
\end{tabular}

The laser sensor made with a laser diode and CCD linear sensor. The laser beam is emitted in the form of laser belt has the width of $39 \mathrm{~mm}$. The laser beam hit (along the $\mathrm{x}$-axis) the tube as shown in Figure 5(b). The tube reflects the beam to the $\mathrm{CCD}$ linear inductive receiver in a certain angle. The controller unit of the sensor process the received optical displacement data of the tube profile $[10,11,12]$. The ID and OD of the tubes were measured along the y-axis with the sensor resolution of $10 \mu \mathrm{m}$. The chamfer angle is measured in the angular direction on the XY plane.

\section{CALIBRATION}

Tubes for the Volkswagen four-cylinder spark-ignition engine (EA827) camshaft shown in Figure 6 is used for this study. The basic size, upper limit, lower limit tolerances of the tube dimensional parameters were shown in Table 3. Three different master tubes were fabricated using the existing production setup with higher accuracy and new tools in the production machines. The algorithm shown in Figure 7 was planned to better envision the schedule of the calibration and measurement programs. The Pneumatic cylinders have the piston positions sensor which can control the position of the pneumatic head in the process. The piston position sensors help to achieve the sequence of operations of the pneumatic circuit. The PLC is programmed to automate the machine sequence. Each programming instruction commands the SPM to execute actions, position, displacement and tube selection or rejection.

Table 3 Tube dimensions and its tolerance limits

\begin{tabular}{|c|c|c|c|c|}
\hline \multirow{2}{*}{ Measurement } & $\begin{array}{c}\text { Basic } \\
\text { Size }\end{array}$ & \multicolumn{2}{|c|}{$\begin{array}{c}\text { Upper/ Lower } \\
\text { limit }\end{array}$} & Range \\
\cline { 2 - 5 } & $\mathrm{mm}$ & $\mathrm{mm}$ & $\mu \mathrm{m}$ & $\mu \mathrm{m}$ \\
\hline Outer Diameter & 24.5 & 0.030 & 30 & 60 \\
\hline $\begin{array}{c}\text { Internal } \\
\text { Diameter }\end{array}$ & 18 & 0.040 & 40 & 80 \\
\hline Length & 329.3 & 0.100 & 100 & 200 \\
\hline $\begin{array}{c}\text { OD run-out (at } \\
\text { the centre) }\end{array}$ & $\begin{array}{c}\text { OD } \\
24.5\end{array}$ & 0.100 & 100 & 200 \\
\hline Measurement & Degree & \multicolumn{2}{|c|}{ Degree } & Degree \\
\hline Chamfer & 90 & \multicolumn{2}{|c|}{2} & 4 \\
\hline
\end{tabular}




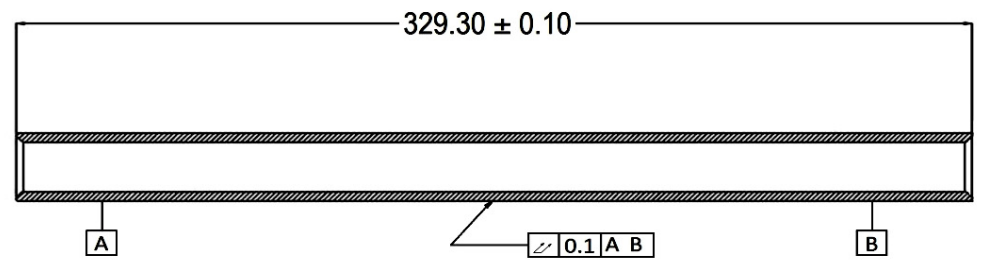

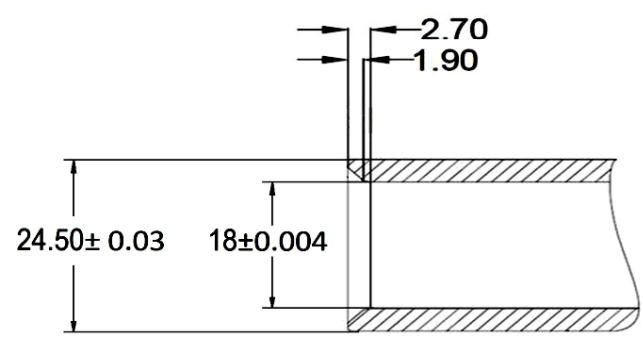

Figure 6 Sectioned 2D view of the tube to be inspected

When the automation sequence started the measuring instruments gets triggered at a particular time to measure the tube dimensional parameters. Calibration and measurements were carried out based on the following steps:

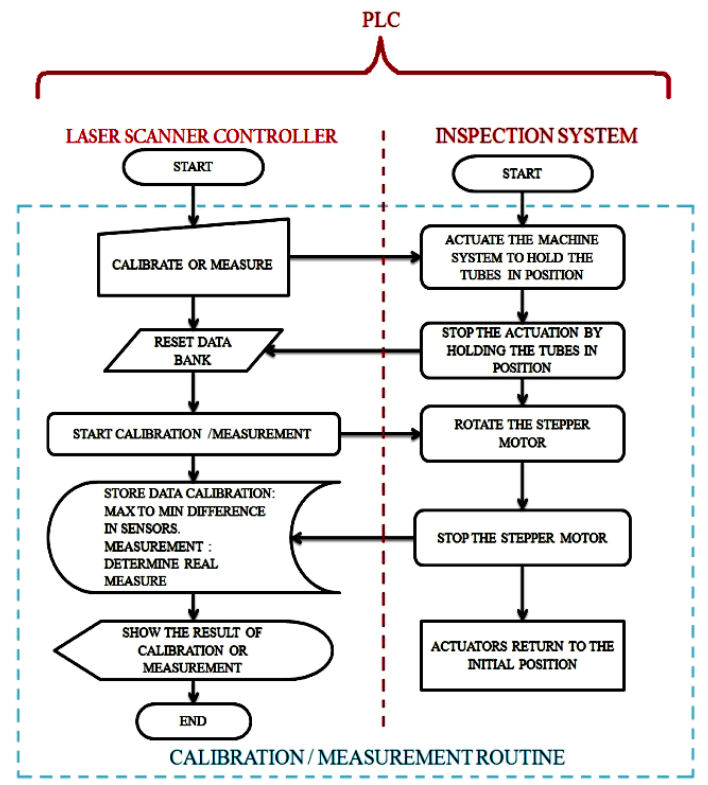

Figure 7 Calibration and measurement routine

- Master tubes are loaded into the corresponding stations.

- Pneumatic actuators get actuated and the tube measurement position was ensured.

- Stepper Motor rotates the tube about its axis (for run-out, ID and OD measurements).

- Measuring sensors scan the master tube and values were averaged for a 30 per sec.

- Sensor value for the master tube is reset to zero value.

- Based on the master tube other tubes from the production are inspected by this SPM.

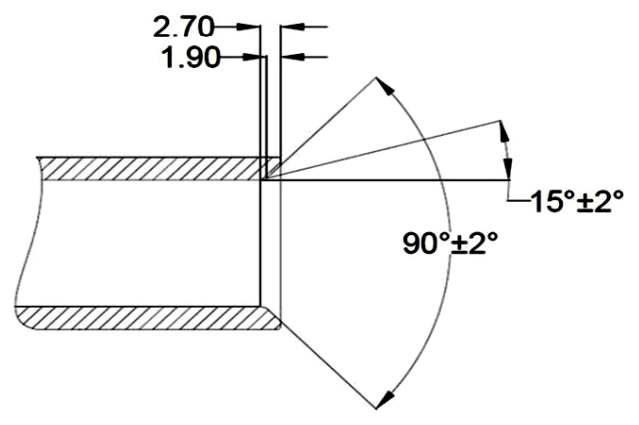

Once calibration is completed on the SPM the master tube is replaced with the tube from the production system continuously. Because the continuous wear takes place between the moving parts of the machine, the inspection values get varied after the completion of thousands of cycles. To avoid the repeatability variation due to wear, periodic master tube calibration is required.

\section{RESULTS AND DISCUSSION}

The master tubes were measured with the Automatic Inspection System (AIS) with five different trials. The tube parameters were measured with Manual Inspection systems. The ID and OD were measured with the internal bore gauge and screw gauge respectively. The length of the tube was measured with the vernier height gauge. The angle of the chamfer was measured with standard high precise balls. The OD runout was measured with the V-blocks and dial gauges. All the manual measurements were done on the surface table.

The results of the manual inspection were compared with the proposed automatic inspection system. Three tubes (test rigs) were selected and several measurements were carried out in both manual and automated system inspection for the tube dimensional inspection parameters such as ID, OD, length, run-out and chamfer angle. Five trials were taken for checking the repeating nature of the Manual inspection instruments and automatic inspection system values. All the values are compared in the following tables.

Because of the low-resolution nature of the manual measuring instruments the length and the OD run-out of the tubes were shown Figur 8. as a straight line for all five trials. In the Case of Length measurement the vernier height gauge shows the result with only second decimal variation because of the low least count $(0.01$ $\mathrm{mm}$ ) compared to 1D laser sensor which is $0.002 \mathrm{~mm}$. Similarly in the case of OD run-out the resolution of the dial gauge is $0.01 \mathrm{~mm}$ but in the case of 1D laser sensor is $0.001 \mathrm{~mm}$ so the measurement with AIS is accurate. 

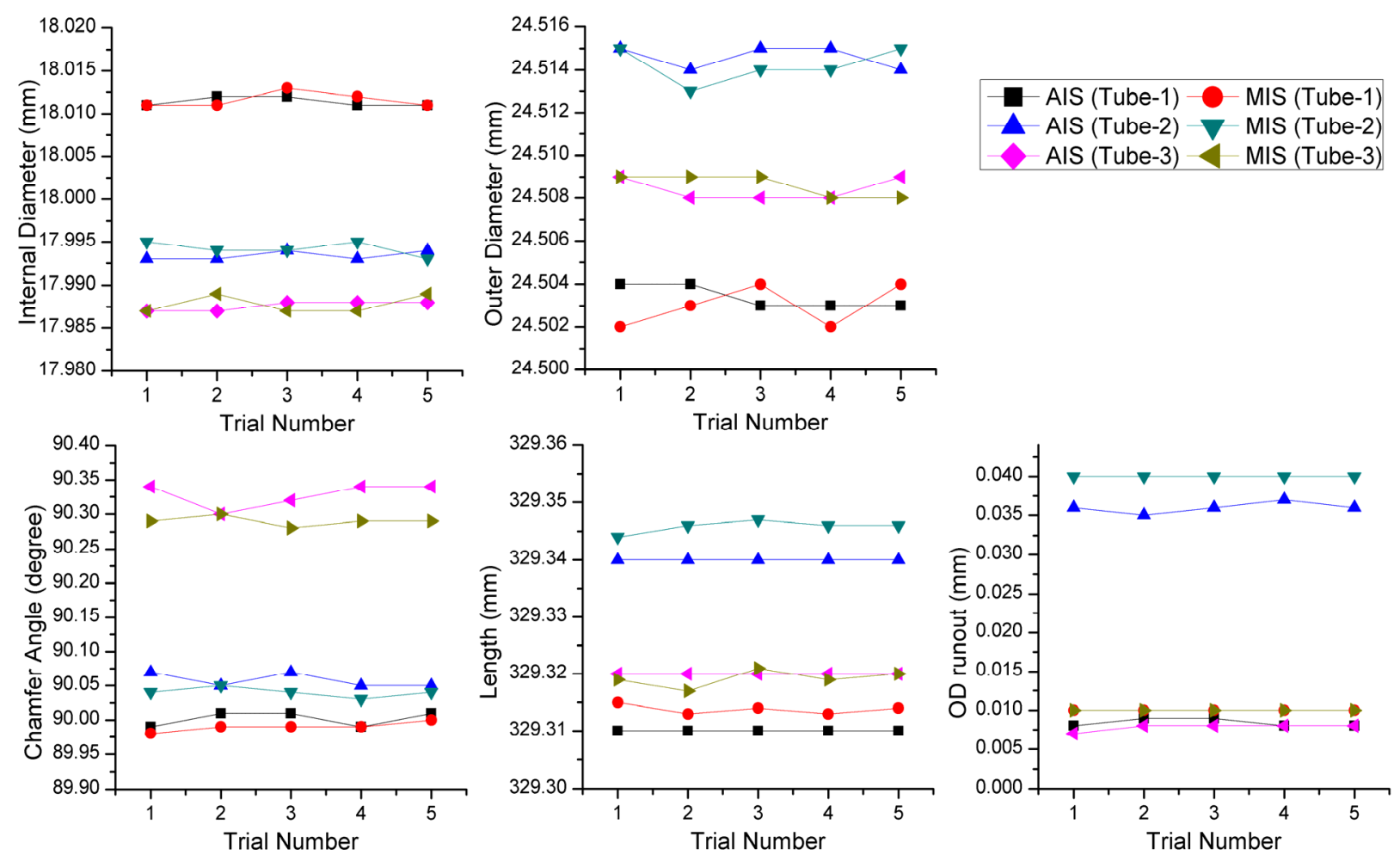

Figure 8 Tube parameters ID, OD, run-out, Chamfer angle, and Length measured values

Table 4. Mean and SD of the measured value with 5 trials

\begin{tabular}{|c|c|c|c|c|c|c|c|c|c|c|c|}
\hline \multirow{3}{*}{\multicolumn{2}{|c|}{ 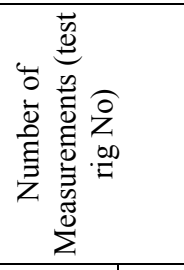 }} & \multicolumn{10}{|c|}{ Results of the measurements test - Test rigs 1,2 , and 3} \\
\hline & & \multicolumn{2}{|c|}{$\begin{array}{c}\text { Inner Diameter } \\
{[\mathrm{mm}]}\end{array}$} & \multicolumn{2}{|c|}{$\begin{array}{c}\text { Outer Diameter } \\
{[\mathrm{mm}]}\end{array}$} & \multicolumn{2}{|c|}{$\begin{array}{c}\text { run-out } \\
{[\mu \mathrm{m}]}\end{array}$} & \multicolumn{2}{|c|}{$\begin{array}{c}\text { Chamfer Angle } \\
\text { [degree] }\end{array}$} & \multicolumn{2}{|c|}{$\begin{array}{l}\text { Length } \\
{[\mathrm{mm}]}\end{array}$} \\
\hline & & A.I.S. & M.I.S & A.I.S. & M.I.S & A.I.S. & M.I.S & A.I.S. & M.I.S & A.I.S. & M.I.S \\
\hline \multirow{3}{*}{ Mean } & (1) & 18.0114 & 18.0116 & 24.5034 & 24.5030 & 0.0088 & 0.01 & 90.002 & 89.99 & 329.31 & 329.313 \\
\hline & $(2)$ & 17.9934 & 17.9942 & 24.5146 & 24.5142 & 0.036 & 0.04 & 90.058 & 90.04 & 329.34 & 329.345 \\
\hline & (3) & 17.9876 & 17.9878 & 24.5084 & 24.5086 & 0.0078 & 0.01 & 90.328 & 90.29 & 329.32 & 329.319 \\
\hline \multirow{3}{*}{ S.D. } & (1) & 0.00054 & 0.00089 & 0.00054 & 0.00100 & 0.0005 & 0.00 & 0.0109 & 0.007 & 0.0000 & 0.00083 \\
\hline & $(2)$ & 0.00054 & 0.00084 & 0.00054 & 0.00084 & 0.0007 & 0.00 & 0.0109 & 0.007 & 0.0000 & 0.00109 \\
\hline & (3) & 0.00054 & 0.00109 & 0.00054 & 0.00054 & 0.0004 & 0.00 & 0.0178 & 0.007 & 0.0000 & 0.00148 \\
\hline
\end{tabular}

\section{CONCLUSION}

This study proposes a tube dimension measurement method based on the 1D and 2D laser displacement sensor to realize the noncontact automatic and dedicated measurement SPM for tubes is possible with $1 \mu \mathrm{m}$ resolution.

The measurement of tube dimensions such as length and OD run-out with 1D laser displacement sensors is proved to be the more viable solution.

The measurement of ID, OD and Chamfer angle of the tube with 2D laser displacement sensor give the most accurate and precise result.

By parallel inspection of the tubular component with the production process, the proposed inspection system will alert the production people, if there is any continuous rejection on the particular tube dimensional parameter. With this the tool of the corresponding machining process can be changed for accurate manufacturing of tubes.

\section{REFERENCES}

[1] Paziani, F.T., Di Giacomo, B. and Tsunaki, R.H., 2007. Development of an automated and dedicated measuring system for straightness evaluation. Journal of the Brazilian Society of Mechanical Sciences and Engineering, 29(3), pp.290-298.

[2] Prieto, F., Redarce, T., Lepage, R. and Boulanger, P., 2002. An automated inspection system. The International Journal of Advanced Manufacturing Technology, 19(12), pp.917-925.

[3] Di Giacomo, B., Silva, R.J. and Paziani, F.T., 2012. Development of an automated and dedicated measuring system for internal diameter inspection. ABCM Symposium series in Mechatronics Vol.5, pp.967-972.

[4] Ji, Z. and Leu, M.C., 1989. Design of optical triangulation devices. Optics \& Laser Technology, 21(5), pp.339-341. 
[5] Zhang, J. and Tan, J.B., 2002. Micro detection system with $\mathrm{nm}$ resolution using self-focal confocal microscope. Journal Of Optoelectronics Laser, 13(4), pp.374-377.

[6] Zhang, Z., Feng, Q., Gao, Z., Kuang, C., Fei, C., Li, Z. and Ding, J., 2008. A new laser displacement sensor based on triangulation for gauge real-time measurement. Optics \& laser technology, 40(2), pp.252-255.

[7] Vacharanukul, K. and Mekid, S., 2005. In-process dimensional inspection sensors. Measurement, 38(3), pp.204-218.

[8] Genta, G., Minetola, P. and Barbato, G., 2016. Calibration procedure for a laser triangulation scanner with uncertainty evaluation. Optics and Lasers in Engineering, 86, pp.11-19.

[9] Son, S., Park, H. and Lee, K.H., 2002. Automated laser scanning system for reverse engineering and inspection. International Journal of Machine Tools and Manufacture, 42(8), pp.889-897.

[10] Xing, Z., Chen, Y., Wang, X., Qin, Y. and Chen, S., 2016. Online detection system for wheel-set size of rail vehicle based on 2D laser displacement sensors. Optik-International Journal for Light and Electron Optics, 127(4), pp.1695-1702.

[11] Guo, Y., Tang, X., Zhou, X., Song, B., Jiang, Z., Xie, Y. and Ye, B., 2018. Continuous measurements with single setup for positiondependent geometric errors of rotary axes on fiveaxis machine tools by a laser displacement sensor. The International Journal of Advanced Manufacturing Technology, pp.1-14.

[12] Guo, Y., Tang, X., Zhou, X., Song, B., Jiang, Z., Xie, Y. and Ye, B., 2018. Continuous measurements with single setup for positiondependent geometric errors of rotary axes on fiveaxis machine tools by a laser displacement sensor. The International Journal of Advanced Manufacturing Technology, pp.1-1.

\section{РАЗВОЈ АУТОМАТИЗОВАНОГ И НАМЕНСКОГ МЕРНОГ СИСТЕМА КОД ДИМЕНЗИЈА ЦЕВИ \\ КОРИШЋЕЊЕМ 1D И 2D ЛАСЕРСКОГ СЕНЗОРА ПОМАКА}

\section{С. Рајан Б., Сатикбаша К., С. Балаји М.А., Харихарасактисудан П.}

Мерење димензија цеви као што је унутрашњи пречник, спољашњи пречник, дужина, угао закошења и излазни спољашњи пречник врши квалификовани техничар уз помоћ конвенционалне мерне опреме. Код система инспекције коју обавља човек постоји могућност грешке приликом инспекције цеви средњих димензија као и код масовне производње цеви. Индустријски захтеви подразумевају велику прецизност и брзину са малом вероватноћом грешке у мерењу у циљу испоруке квалитетнијег производа. Циљ рада је развој аутоматизованог и наменског система инспекције који обухвата унутрашњи пречник, спољашњи пречник, дужину, угао закошења и излазни спољашњи пречник цевних компонената (као што су брегаста осовина, ваздушни амортизери, итд.) коришћењем 1d и 2d ласерског сензора помака. Унутрашњи и спољашњи пречник и угао закошења (унутрашњи угао закошења на оба краја цеви) су мерени помоћу $2 \mathrm{~d}$ ласерског сензора помака. Ласерски сензор $1 \mathrm{~d}$ је коришћен за мерење излазног спољашњег пречника и дужине цеви. Калибрација сензора је извршена главном мерном цеви и извршено је поређење са методом мануелне инспекције. 